\title{
Knowledge, attitude and practice regarding pharmacological methods of labor analgesia
}

\author{
Conhecimento, atitude e prática em relação aos métodos farmacológicos de analgesia de parto
}

Bianca Ruschel Hillmann ${ }^{1}$, Ana Maria Nunes de Faria Stamm²

DOI 10.5935/2595-0118.20190004

\section{ABSTRACT}

BACKGROUND AND OBJECTIVES: Labor pain is caused by several physiological changes and may cause psychological damage to the parturient and her relatives and, therefore, must be relieved. The objective of this study was to evaluate the knowledge, attitude, and practice of obstetricians concerning pharmacological methods of labor analgesia.

METHODS: Cross-sectional study (38 obstetricians working at public maternity hospitals). A structured questionnaire was applied about knowledge, attitude and practice concerning systemic and regional pharmacological methods. The agreement magnitude was assessed by kappa coefficient.

RESULTS: We observed adequate knowledge about the indications of all methods (31 to $86 \%$ ), the contraindications of opioids (92\%) and the adverse effects of non-opioid analgesics lantispasmodics on the fetus (76\%). Concerning attitude, they agree that non-opioid analgesics/antispasmodics do not minimize labor pain $(98 \%)$ but should be available at the maternity wards $(89 \%)$ and that epidural analgesia is effective (100\%) and should be available (94\%). In practice, the indication of non-opioid analgesics/antispasmodic and epidural analgesia prevailed. In most of the requirements in each dimension (knowledge: $\mathrm{K}=-$ 0.092 to $0.158 ; \mathrm{p}=0.057$ to 1.0 and attitude: $\mathrm{K}=-0.005$ to 0.472 ; $\mathrm{p}=0.004$ to 1.0 ), there was minimal agreement with practice, except for the non-opioid analgesics/antispasmodics $(K=0.421$, $\mathrm{p}=0.009)$, and epidural analgesia $(\mathrm{K}=0.472, \mathrm{p}=0.004)$, with a moderate agreement.

CONCLUSION: Knowledge was heterogeneous. The attitude was unanimous concerning the effectiveness and the need of

Bianca Ruschel Hillmann - (Dhttps://orcid.org/0000-0003-0063-2385;

Ana Maria Nunes de Faria Stamm - Dhttps://orcid.org/0000-0001-5186-1247.

1. Hospital Regional de São José, Departamento de Ginecologia, Florianópolis, SC, Brasil. 2. Universidade Federal de Santa Catarina, Centro de Ciências da Saúde, Departamento de Clínica Médica, Florianópolis, SC, Brasil.

Submitted in October 12, 2018.

Accepted for publication in December 14, 2018.

Conflict of interests: none - Sponsoring sources: none

Correspondence to:

Rua Eng. Agronômico Andrei Cristian Ferreira, s/n - Trindade

88040-900 Florianópolis, SC, Brasil.

E-mail: biancahillmann@gmail.com

(C) Sociedade Brasileira para o Estudo da Dor having epidural available, and the ineffectiveness of non-opioid analgesics/ antispasmodics, and the practice of prescribing them. There was a minimal agreement between knowledge and practice, and between attitude and practice on most of the other requirements in each dimension.

Keywords: Analgesia, Attitude and practice in health, Childbirth pain, Knowledge, Medical education, Obstetric analgesia, Pharmacological treatment.

\section{RESUMO}

JUSTIFICATIVA E OBJETIVOS: A dor do parto é causada por diversas alteraçóes fisiológicas e pode causar danos psicológicos à parturiente e seus familiares, portanto, deve ser aliviada. O objetivo deste estudo foi avaliar o conhecimento, atitude e prática de obstetras sobre métodos farmacológicos de analgesia de parto.

MÉTODOS: Estudo transversal, com amostra de conveniência (38 obstetras que atuam em maternidades públicas). Foi aplicado um questionário estruturado sobre conhecimento, atitude e prática em relação a métodos farmacológicos sistêmicos e regionais. Magnitude de concordância avaliada pelo coeficiente Kappa.

RESULTADOS: Observou-se conhecimento adequado nas indicaçóes de todos os métodos (31 a 86\%), contraindicaçóes dos opioides (92\%) e efeitos adversos de analgésicos simples/antiespasmódicos no feto (76\%). $\mathrm{Na}$ atitude, concordam que os analgésicos simples/antiespasmódicos não funcionam no alívio da dor do parto (98\%), mas devem estar disponíveis nas maternidades (89\%), e que a analgesia peridural é eficaz (100\%) e deve estar disponível (94\%). Na prática, prevaleceu a indicação de analgésicos simples/antiespasmódicos e da analgesia peridural. Na maioria dos quesitos, em cada dimensão (conhecimento: $\mathrm{K}=-0,092$ a 0,$158 ; \mathrm{p}=0,057$ a 1,0 e atitude: $\mathrm{K}=-0,005$ a 0,472 ; $\mathrm{p}=0,004$ a 1,0$)$, houve concordância mínima com a prática, excetuando analgésicos simples/antiespasmódicos $(K=0,421$; $\mathrm{p}=0,009)$ e analgesia peridural $(\mathrm{K}=0,472 ; \mathrm{p}=0,004)$, com concordância moderada.

CONCLUSÃO: O conhecimento foi heterogêneo. A atitude foi unânime quanto à eficácia e necessidade da analgesia peridural estar disponível, e ineficácia dos analgésicos simples e antiespasmódicos, e a prática de prescrevê-los. Houve concordância mínima entre o conhecimento e a prática, e entre a atitude e a prática, na maioria dos outros quesitos em cada uma das dimensóes.

Descritores: Analgesia, Analgesia obstétrica, Atitudes e prática em saúde, Conhecimentos, Dor do parto, Educação médica, Tratamento farmacológico. 


\section{INTRODUCTION}

Childbirth pain is caused by a number of physiological changes that occur in the body of the woman in labor, such as cervical dilatation, strain of the uterine fibers and the birth canal, traction of the ovaries and peritoneum, and compression of pelvic structures and roots of the lumbar-sacral plexus ${ }^{1,2}$. This pain leads to anxiety and apprehension, with increased secretion of cortisol and catecholamines, which may alter contractility and uterine flow, affecting the course of labor and fetal well-being ${ }^{1}$. Pain can also cause psychological stress to the woman in labor and her relatives, making it difficult to interact with the newborn ${ }^{2}$ and, therefore, requiring relief'.

The major challenges of analgesia during labor are adverse effects on the fetus and the need to avoid excessive sedation of the patient so that she is cooperative, and the mother-baby bond can be established after birth ${ }^{2,3}$. Considering these limitations, several analgesic methods have been developed for pain control, including systemic and regional non-pharmacological and pharmacological methods ${ }^{1}$.

Among the pharmacological methods, the systemic can be administered intravenously, intramuscularly or by inhalation ${ }^{1}$, and the parenteral analgesia can be performed with non-opioid drugs (antihistamines, antispasmodics, non-opioid analgesics, and anti-inflammatories) or opioids (such as morphine, dolantin, and remifentanil). However, the regional methods - pudendal nerve block, spinal analgesia, and epidural analgesia - are often preferred as they do not affect fetal well-being ${ }^{1}$.

Considering the pharmacological systemic and regional methods, their indications, contraindications and adverse effects, one can notice the decision-making complexity, as well as the need to monitor the mother-baby binomial during their use. Despite these potential difficulties, it is essential for the obstetrician to handle them since many women in labor do not present a satisfactory degree of pain relief when submitted only to non-pharmacological methods.

Therefore, we propose a study to evaluate the knowledge, attitude, and practice (KAP) of obstetricians working in public maternity hospitals in southern Brazil, with regard to the main current pharmacological methods of childbirth analgesia. We believe that this type of research can capture what a group knows about a particular subject (knowledge), feelings and preconceived ideas in relation to the topic (attitude) and how they demonstrate this knowledge and attitude in their actions (practice) ${ }^{4}$.

The study also aims at describing the characteristics of the study population, the degree of agreement between these three dimensions, relating them to age and length of service in the delivery room, and the satisfaction of these professionals with the labor analgesia offered to their patients.

\section{METHODS}

A cross-sectional, observational, descriptive and analytical study conducted from July to November 2016. Fifty obstetricians working in three public maternity hospitals in southern Brazil, which are part of the program Hospital Amigo da Criança [Children's
Friend Hospital], were invited to participate in the research. Of these, 38 professionals made up the convenience sample.

A structured questionnaire with open and closed questions and space for comments at the end was prepared based on studies on $\mathrm{KAP}^{5-11}$; the theoretical basis on the subject ${ }^{12-20}$ and research ${ }^{21,22}$. The questionnaire was divided into three parts:

1. Characteristics of the study population, including questions about prototypes of pharmacological methods of labor analgesia. 2. Dimension of knowledge, attitude and practice of obstetricians regarding these methods. Theoretical knowledge related to the subtopics indications, contraindications and potential adverse effects on the woman in labor and the fetus, with open questions. Attitude, encompassing three subtopics - Does it work in relieving labor pain? Do the benefits outweigh the risks? Should it be available for use in the maternity ward? - with answers in Likert scale (5 options), and practice with one subtopic - Do you prescribe the method or not?

3 . The level of satisfaction of these professionals with the pharmacological labor analgesia offered to the patients in these health institutions.

The instrument was evaluated by two experts in this area, who analyzed the form of presentation and the content, relating these elements to the tool's ability to capture the phenomenon under study. The suggested changes were accepted.

The research was approved by the Human Research Ethics Committee of the university to which the researchers are affiliated - project number 51673515.2.0000.0121 - and carried out after signing the Free and Informed Consent Term (FICT), in accordance with the resolution 196/96/MS of the Brazilian National Health Council.

\section{Statistical analysis}

It was performed using IBM's Statistical Package for Social Sciences (SPSS) software, version 23.0.

Responses regarding age and length of service were considered in full years. As for the prototypes mentioned by the participants, the order in which they were written was respected.

In the knowledge dimension, for each participant's response to the subtopics, we assigned either the grade "appropriate" - when there were at least $30 \%$ of correct answers and no incorrect answer - and "inappropriate", in the remaining cases. This evaluation was made using as reference a template developed from the literature review ${ }^{12-20}$. The level of knowledge of the study population was considered excellent (when more than $75 \%$ of the participants showed adequate knowledge on that question), good (between 50 and 75\%), moderate (between 25 and 50\%) and low (less than $25 \%)^{6}$.

In the attitude dimension, the answers were dichotomized into "yes" and "no" and, in the practice dimension, into "prescribes" and "does not prescribe".

The categorical variables were expressed in absolute numbers and proportions, while the continuous variables with normal distribution (measured by the Kolmogorov-Smirnov test) were expressed as mean and standard deviation (SD).

The magnitude of agreement between knowledge and practice, and between attitude and practice was evaluated by Cohen's kappa coefficient, using the cut-off points proposed by Landis and Koch ${ }^{23}$. 
The relationship between continuous variables (age and length of service in the delivery room) and categorical variables (knowledge, attitude and practice) was assessed by the Student's t-test. A $\mathrm{p}<0.05$ was considered significant.

\section{RESULTS}

Of the 50 obstetricians who work at three public maternity hospitals in southern Brazil, 76\% (38) participated in the study.

The mean age was $44 \pm 9$ years and the mean length of time practicing in the delivery room was $16 \pm 9$ years. All of them have postgraduate degrees in gynecology and obstetrics residency, and one third $(33 \%, 13 / 38)$ has a second specialization.

When asked to inform three pharmacological methods of childbirth analgesia (prototypes) ${ }^{24}$, the most cited methods were epidural analgesia $(42 \%, 16 / 38)$, antispasmodic drugs $(31 \%$, $12 / 38)$, and parenteral opioids $(15 \%, 6 / 38)$.

The majority $(68 \% ; 26 / 38)$ expressed dissatisfaction with the quality of labor analgesia offered to patients in the maternity ward where they work, with 26\% (10/38) partially satisfied and only $5 \%(2 / 38)$ satisfied.

We observed a good knowledge of simple and antispasmodic analgesics in terms of indications $(73 \%, 28 / 38)$, and excellent in terms of adverse effects on the fetus $(76 \%, 29 / 38)$. In the opioid category, knowledge was excellent in terms of indications $(86 \%$,

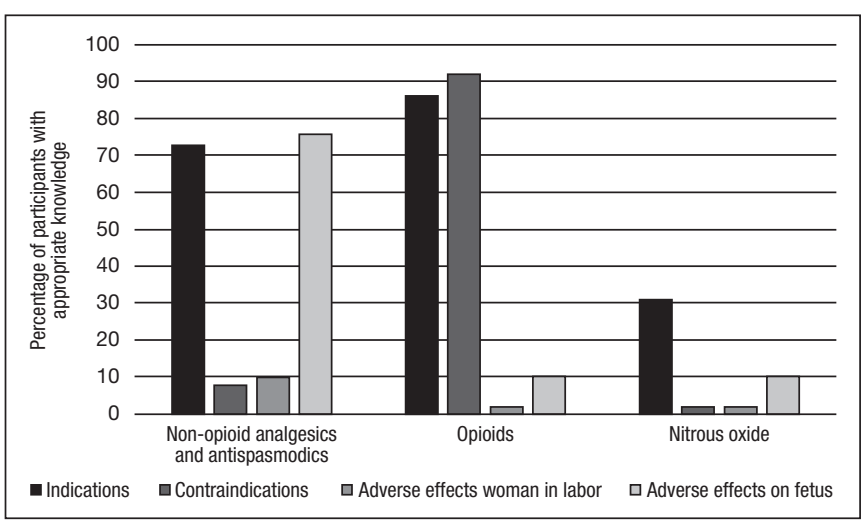

Figure 1. Obstetricians' knowledge degree regarding pharmacological systemic methods of labor analgesia

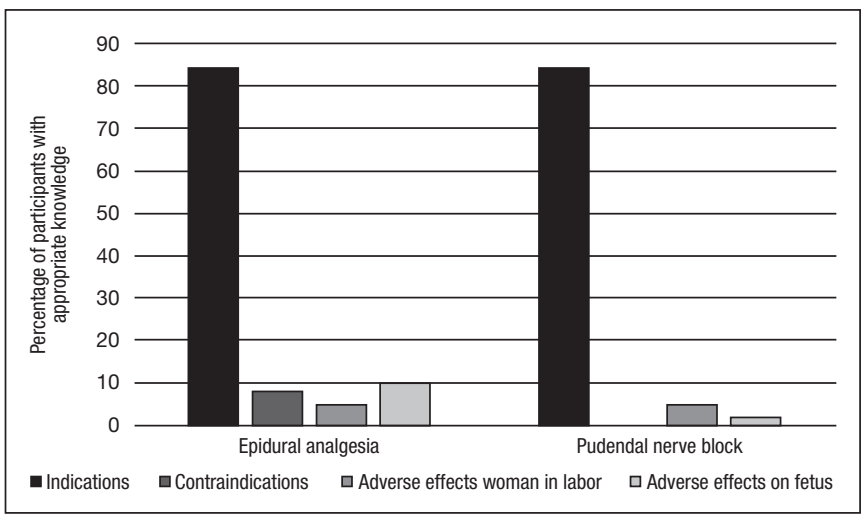

Figure 2. Obstetricians' knowledge degree regarding regional pharmacological methods of labor analgesia
$33 / 38)$ and contraindications (92\%, 35/38); as for nitrous oxide, we observed a moderate degree of knowledge regarding indications $(31 \%, 12 / 38)$ (Figure 1).

As for regional methods of labor analgesia, the degree of knowledge was excellent regarding the indications of epidural analgesia $(84 \%, 32 / 38)$ and pudendal nerve block $(79 \%, 30 / 38)$ (Figure 2).

As for non-opioid analgesics and antispasmodics, approximately half of the participants $(47 \%, 18 / 38)$ believe that the benefits outweigh the risks in most cases, and that they should be available in maternity wards $(89 \%, 34 / 38)$, knowing that they do not relieve labor pain. As for opioids, even though the majority of the participants indicate that opioids should be available $(92 \%$, $35 / 38)$, 39\% (15/38) believe that this method is effective. In the case of nitrous oxide, 29\% (11/38) indicate that it should be available in maternity wards (Figure 3 ).

With regard to epidural analgesia, the participants were unanimous about its effectiveness (100\%) and the need to be available in maternity wards (94\%), with $47 \%$ believing that the benefits outweigh the risks. As for pudendal nerve block, merely an attitude that it should be available in the maternity wards prevails (63\%) (Figure 4). The prescription of non-opioid analgesics and antispasmodics $(50 \%, 19 / 38)$ was similar to that of epidural $(47 \%, 18 / 38)$, followed by pudendal nerve block $(21 \%, 8 / 38)$ and opioids $(21 \%$; $8 / 38)$. There was no reference to the prescription of nitrous oxide.

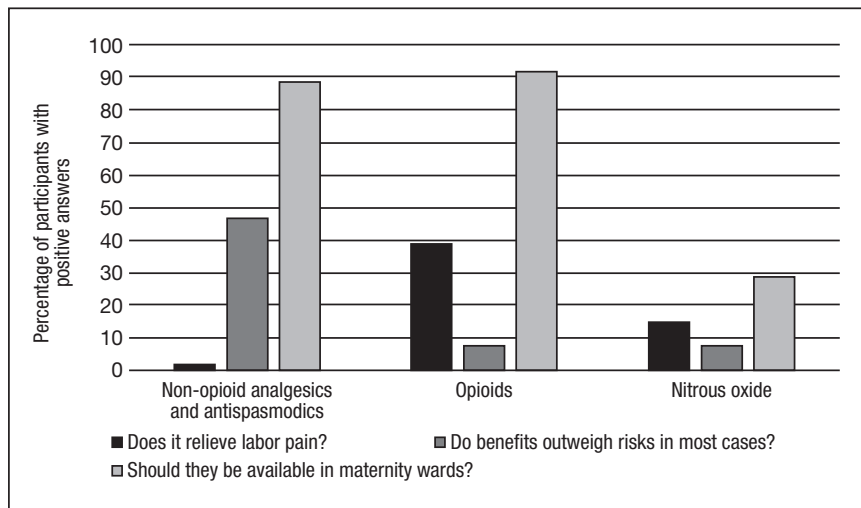

Figure 3. Obstetricians' attitude regarding systemic pharmacological methods of labor analgesia

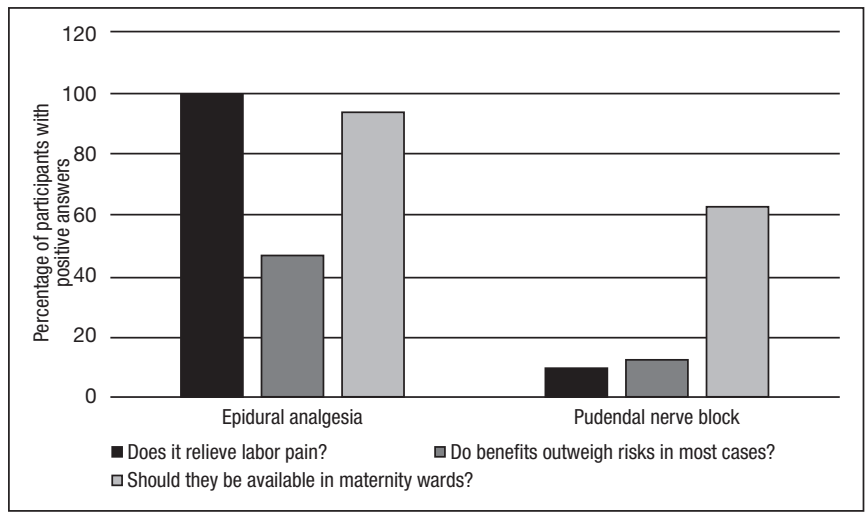

Figure 4. Obstetricians' attitude regarding regional pharmacological methods of labor analgesia 


\section{Analytical statistics}

The Kappa analysis showed reasonable agreement for opioids $(\mathrm{k}=0.281, \mathrm{p}=0.043)$ and moderate agreement for non-opioid analgesics and antispasmodics $(\mathrm{k}=0.421, \mathrm{p}=0.009)$ and epidural $(\mathrm{k}=0.472, \mathrm{p}=0.004)$, between ATTITUDE - question "Do benefits outweigh risks in most cases?" and medical PRACTICE. Reasonable agreement $(\mathrm{k}=0.211 ; \mathrm{p}=0.034)$ was also observed for non-opioid analgesics and antispasmodics between ATTITUDE - question "Should they be available in maternity wards?" and PRACTICE. In most other questions, in each dimension (knowledge: $\mathrm{k}=-.092$ to 0.158 ; $\mathrm{p}=0.057$ to 1.0 ; and attitude: $\mathrm{k}=-$ 0.005 to $0.472 ; \mathrm{p}=0.004$ to 1.0 ), there was minimum degree of agreement with practice.

When assessing opioids and relating knowledge, attitude and practice to the age of the participants, there was a statistically significant difference between the mean ages in the ATTITUDE dimension - question "Do you believe they should be available in maternity wards?", with a mean of 45 and 34 years for positive and negative responses, respectively (mean difference $=11$ years, Student's $t=2.068 ; 95 \% \mathrm{CI}=0.215-22.128, \mathrm{p}=0.046)$. In the PRACTICE dimension, the mean age was 38 and 45 years for positive and negative responses, respectively (difference $=7$ years, Student's $\mathrm{t}=-2.064 ; 95 \% \mathrm{CI}=-14.690-0.120 ; \mathrm{p}=0.047)$.

There was also a significant difference in ATTITUDE related to pudendal nerve block - question: "Do you believe it relieves labor pain?" - with the mean age being 52 years and 43 years for positive and negative responses, respectively (difference $=9$ years; Student's $\mathrm{t}=3.002 ; 95 \% \mathrm{CI}=1.918-14.582 ; \mathrm{p}=0.017$ ).

The relation between the average length of time working in the delivery room and knowledge, attitude and practice, showed a statistically significant difference regarding opioids in the dimension KNOWLEDGE - question "adverse effects on the fetus" - with an average of 7 years in the "adequate" responses and 17 years in the "inadequate" response (difference $=10$ years; Student's $t=-2.040 ; 95 \% \mathrm{CI}=-20.295-0.058 ; \mathrm{p}=0.049$ ). In the dimension ATTITUDE - question "Do you believe it should be available in maternity wards?" - there was an average of 17 years in those with a positive response and 5 years in those with a negative response (difference $=12$ years; Student's $t=2.062 ; 95 \%$ $\mathrm{CI}=0.193$ - 23.198; $\mathrm{p}=0.046$ ).

There was also a statistically significant difference in relation to the length of time working in the delivery room regarding pudendal nerve block, in the dimension ATTITUDE - "Do you believe it relieves labor pain?", with an average of 23 years in participants with a positive response, and 15 years with a negative response (difference $=8$ years; Student's $\mathrm{t}=3.330 ; 95 \% \mathrm{CI}=3.002$ $-14.069 ; \mathrm{p}=0.005)$.

\section{Comments}

Among the 13 participants $(34.2 \%, 13 / 38)$ who made comments, 6 mentioned it was difficult to have access to pharmacological methods in general, 6 mentioned epidural analgesia was unavailable due to the absence of an anesthesiologist in the obstetric center or their refusal to provide it, and 2 participants cited the professionals' and patients' lack of knowledge about analgesia methods.

\section{DISCUSSION}

It is important that the patient in labor is offered pain relief methods to avoid trauma and increase the degree of satisfaction in order to facilitate the interaction of the baby with the family. In two studies conducted on the African continent, it was observed that most professionals believe that pain relief is necessary during childbirth ${ }^{25,26}$, but approximately half of them did not administer any analgesic method (48\%), and of these, more than half $(54 \%)$ did not mention reasons for this ${ }^{25}$, while some still believe that analgesia is not necessary because childbirth pain is a natural process ${ }^{26}$.

In this scenario, we can still consider that the patient may have different needs throughout labor - and may use more than one method of analgesia - which highlights the importance of the obstetricians to have knowledge, attitude and confidence in the use the pharmacological methods available at their workplace, choosing the best method in each situation. This is evidenced in the comments of the participants, because hospitals from the Brazilian public healthcare system (SUS) do not always have professionals to perform epidural analgesia.

The literature has shown that non-opioid analgesics and antispasmodics cannot be considered methods of labor analgesia because they are not effective ${ }^{12,13}$. Although $98 \%$ of participants believe in their ineffectiveness, this method is one of the prototypes of labor analgesia in the minds of these obstetricians and one of the most prescribed methods. This ambivalence among knowledge, attitude and practice may be because these drugs show a low risk to the fetus and low interference on the course of labor and, although they do not relieve pain, they increase the satisfaction with the care provided and with the delivery when compared to placebo $^{14,15}$.

Adequate knowledge about the indications and contraindications of opioids was observed, but only $40 \%$ of the participants believe in their effectiveness, regardless of what research on this topic shows ${ }^{3,14,16}$. Most assure that the risks do not outweigh the benefits, an attitude that is corroborated by practice, by not prescribing them (4/5 of the participants), which is in agreement with the guidelines of the Brazilian Department of Health that they should not be used routinely ${ }^{17}$.

The mean age of participants who prescribe opioids is lower than that of non-prescribers, which may be due to an accumulation of negative experiences with the use of these drugs over time.

Nitrous oxide, which has been used in labor analgesia in many countries for decades, for its effectiveness and low risks ${ }^{14,18}$, is a method unknown to participants, who also consider that its risks do not outweigh the benefits and do not prescribe it. This may reflect the Brazilian reality because, although this gas is commonly available for use in general anesthesia, few hospitals use it during childbirth.

The degree of knowledge about the indications for epidural analgesia was adequate, with a positive attitude regarding its effectiveness (100\% of respondents), benefits that outweigh risks (45\%), and availability in maternity wards (95\%), besides being one of the most prescribed methods and the most cited prototype. There was also a tendency for the attitude of believing 
that benefits outweigh risks leading to the practice of prescribing it. Currently, this is the most effective method of analgesia, ${ }^{1,14}$ and, therefore, it should be available in all maternity wards ${ }^{19,20}$. Of the pharmacological methods, it is the only one that is administered by anesthesiologists, and not by obstetricians, ${ }^{14}$ but it is crucial that the knowledge of whoever indicates it is extended to its contraindications and adverse effects, to avoid the bias of patient selection and inadequate monitoring of its adverse effects. Regarding pudendal nerve block, we observed that the physicians also had adequate knowledge about its indications and, although most believe that it should be available, the attitude of believing in its ineffectiveness prevails, and that its benefits do not outweigh the risks. In practice, those who do not prescribe it prevail (4/5 of the participants).

It was also observed that obstetricians with a higher mean age and longer time working in the delivery room tend to believe in the effectiveness of pudendal nerve block more frequently than younger obstetricians with less time working in this area. This relationship may reflect a decrease in the indication for episiotomy and an increase in the use of the vacuum extraction over forceps in recent years, having an impact on its indication as a method of labor analgesia ${ }^{27-29}$.

The convenience sample of this study highlights the qualification of professionals working in public maternity wards and hospitals, who in order to get a position in these healthcare institutions had to be approved in a selection process and demonstrate experience in the delivery room. This allows us to infer the competence of these obstetricians in their respective fields of work. Nevertheless, it is clear that among the available methods, knowledge does not always cover the range of questions and, in practice, the most prescribed methods are simple analgesics, antispasmodics and epidural analgesia.

We observed a minimum degree of agreement between knowledge and practice, and between attitude and practice in most of the subtopics of each dimension, and reasonable to moderate in the others, this fact being common to other studies that take this methodology into account ${ }^{5-7}$.

The lack or absence of public policies in the regulation of labor analgesia methods, combined with what the Department of Education and Culture advocates as a proposal for a medical residency program, in which this topic is neither emphasized nor addressed $^{30}$, and the possibility of memory bias when sampling the data ${ }^{24}$, are potential limitations to be considered.

Considering that most of the participants are not satisfied with the childbirth analgesia provided to patients, which may reflect the difficulties encountered for performing epidural analgesia, we suggest studies on the perception of women in labor concerning the analgesia received.

\section{CONCLUSION}

Regarding knowledge, attitude and practice of obstetricians working at three public maternity hospitals in southern Brazil, we concluded that good to excellent knowledge prevailed in relation to the indication of regional pharmacological methods, opioid contraindications, and adverse effects of simple and antispasmo- dic analgesics, while it was low in the other subtopics of this dimension.

In general, participants have a positive attitude regarding epidural and non-opioid analgesics and antispasmodics, and a negative attitude regarding the remaining methods.

The most prescribed methods by obstetricians are non-opioid analgesics/ antispasmodics and epidural, with less expressive numbers or absence of other methods.

\section{REFERENCES}

1. Anjos KF, Santos VC, Souzas R. Parto, aborto e puerpério: assistência humanizada à mulher. Rev Bras Ginecol Obstet. 2010;13(1):44-55.

2. Camano LSE. Assistência ao Parto e Tocurgia. 2002. 1-324 p.

3. Anderson D. A review of systemic opioids commonly used for labor pain relief. J Midwifery Womens Health. 2011;56(3):222-39. Erratum in: J Midwifery Womens Health. 2011;56(4):411-8.

4. Kaliyaperumal K. Guideline for conducting a knowledge, attitude and practice (KAP) study. Community Ophthalmol. 2004;4(1):7-9.

5. Wang Y, Zhu R, Huang N, Li W, Yang L, Zhang S, et al. Knowledge, attitudes, and practices survey of drug allergy among healthcare practitioners in central China: a multicenter study. Asia Pac Allergy. 2016;6(2):105-11.

6. Magalhāes VC, Oliveira DL, Prado FO. Knowledge, risk perception and attitudes of Dentistry students with regard to HIV/AIDS. RGO, Rev Gaúch Odontol. 2015;63(3):291-300

7. Silveira NS, Vasconcelos CT, Nicolau AI, Oriá MO, Pinheiro PN, Pinheiro AK. Knowledge, attitude and practice of the smear test and its relation with female age. Rev Lat Am Enfermagem. 2016;24. English, Portuguese, Spanish.

8. Colak D, Oguz A, Yazilitas D, Imanaglu IG, Altinbas M. Morphine: patient knowledge and attitudes in the central anatolia part of Turkey. Asian Pac J Cancer Prev. 2014;15(12):4983-8

9. Lopes FS, Duarte AC, Gusman PB, Silva D, Ganem EM, Barros GA. Evaluation of the knowledge of postoperative pain among participants of a virtual scientific journey in Anesthesiology. Rev Dor. 2016;17(2):111-6.

10. Ke LS, Chiu TY, Lo SS, Hu WY. Knowledge, attitudes, and behavioral intentions of nurses toward providing artificial nutrition and hydration for terminal cancer patients in Taiwan. Cancer Nurs. 2008;31(1):67-76.

11. Dias IM, Almeida SM, Dias JM, Leite IC. 'Specialists' perception and opinion about self-medication of patients with temporomandibular disorders and orofacial pain. Rev Dor. 2017;18(1):32-7

12. Novikova N, Cluver C. Local anaesthetic nerve block for pain management in labour Cochrane Database Syst Rev. 2012;(4):CD009200.

13. Uptodate. Scopolamine systemic drug information. 2017 [cited 2017 Jul 20]. Available from: https://www.uptodate.com/contents/scopolamine-systemic-drug-information.

14. Jones L, Othman M, Dowswell T, et al. Pain management for women in labour: an overview of systematic reviews. Cochrane Database Syst Rev. 2013;(6):CD009234.

15. Othman M, Jones L, Neilson JP. Non-opioid drugs for pain management in labour. Cochrane Database Syst Rev. 2012;(7):CD009223.

16. Tveit TO, Halvorsen A, Seiler S, Rosland JH. Effectiveness and adverse effects of intravenous remifentanil patient-controlled analgesia used in a stepwise approach for labour: an observational study. Int J Obstet Anesth. 2013;22(1):19-25.

17. Ministério da Saúde. Diretrizes Nacionais de Assistência ao Parto Normal. 2017. 53p

18. Klomp T, van Poppel M, Jones L, Lazet J, Di Nisio M, Lagro-Janssen AL. Inhaled analgesia for pain management in labour. Cochrane Database Syst Rev. 2012;(9):CD009351.

19. Gilbert J Grant M. Pharmacologic management of pain during labor and delivery. Uptodate; 2017 [cited 2017 Jul 20]. Available from: https://www.uptodate.com/contents/pharmacologic-management-of-pain-during-labor-and-delivery? source=search_result\&search=analgesia+de+parto\&selectedTitle $=1 \sim 37$.

20. Anim-Somuah M, Smyth RM Jones L. Epidural versus non-epidural or no analgesia in labour. Cochrane Database Syst Rev. 2011;(12):CD000331.

21. Gil AC. Como elaborar projetos de pesquisa. São Paulo. Atlas S.A; 2002. 175p.

22. Pereira JCR. Análise de dados qualitativos: Estratégias Metodológicas para as Ciências da Saúde, Humanas e Sociais. $3^{a}$ ed.1.reimpr. São Paulo: Editora da Universidade de Săo Paulo; 2004.

23. Landis JR, Koch GG. The measurement of observer agreement for categorical data Biometrics. 1977;33(1):159-74.

24. Kim YY, Park JH, Kang HJ, Lee EJ, Ha S, Shin SA. Level of agreement and factors associated with discrepancies between nationwide medical history questionnaires and hospital claims data. J Prev Med Public Health 2017;50(5):294-302.

25. Ogboli-Nwasor E, Adaji S, Bature S, Shittu O. Pain relief in labor: a survey of awareness, attitude, and practice of health care providers in Zaria, Nigeria. J Pain Res. 2011;4:227-32.

26. McCauley M, Stewart C, Kebede B. A survey of healthcare providers knowledge and attitudes regarding pain relief in labor for women in Ethiopia. MC Pregnancy Child- 
birth. 2017;17(1):56.

27. Escuriet R, Pueyo ML, Perez-Botella M, et al. Cross-sectional study comparing public and private hospitals in Catalonia: is the practice of routine episiotomy changing? BMC Health Serv Res. 2015;11;15:95.

28. Chehab M, Courjon M, Eckman-Lacroix A, Ramanah R, Maillet R, Riethmuller D. [Impact of a major decrease in the use of episiotomy on perineal tears in a level III maternity ward]. [Article in French] J Gynecol Obstet Biol Reprod. 2014;43(6):463-9.
29. Hehir MP, Reidy FR, Wilkinson MN, Mahony R. Increasing rates of operative vaginal delivery across two decades: accompanying outcomes and instrument preferences. Eur J Obstet Gynecol Reprod Biol. 2013;171(1):40-3.

30. Ministério de educaçáo e cultura. proposiçấo de conteúdo dos programas de residência médica. 2006. Available from: http://portal.mec.gov.br/ index.php?option=com_docman\&view=download\&alias=6511-ginecologia-obstetricia-sesu-rm\&Itemid=30192. 